\title{
Analysis of flash flood regimes in the North-Western and South-Eastern Mediterranean regions
}

\author{
P. Tarolli ${ }^{1}$, M. Borga ${ }^{1}$, E. Morin ${ }^{2}$, and G. Delrieu ${ }^{3}$ \\ ${ }^{1}$ Department of Land, Environment, Agriculture and Forestry, University of Padova, Legnaro, Italy \\ ${ }^{2}$ Department of Geography, The Hebrew University of Jerusalem, Mount Scopus, Jerusalem, Israel \\ ${ }^{3}$ Laboratoire d'etude des Transferts en Hydrologie et Environnement, Grenoble, France \\ Correspondence to: P. Tarolli (paolo.tarolli@unipd.it)
}

Received: 10 January 2012 - Revised: 8 March 2012 - Accepted: 16 March 2012 - Published: 3 May 2012

\begin{abstract}
This work analyses the prominent characteristics of flash flood regimes in two Mediterranean areas: the NorthWestern Mediterranean region, which includes Catalonia, France and Northern Italy, and the South-Eastern Mediterranean region, which includes Israel. The two regions are characterized by similarities in the hydro-meteorological monitoring infrastructure, which permits us to ensure homogeneity in the data collection procedures. The analysis is articulated into two parts. The first part is based on use of flood peak data, catchment area and occurrence date for 99 events (69 from the North-Western region and 30 from the South-Eastern region). Analysis is carried out in terms of relationship of flood peaks with catchment area and seasonality. Results show that the envelope curve for the SouthEastern region exhibits a more pronounced decreasing with catchment size with respect to the curve of the North-Western region. The differences between the two relationships reflect changes in the effects of storm coverage and hydrological characteristics between the two regions. Seasonality analysis shows that the events in the North-Western region tend to occur between August and November, whereas those in the South-Eastern area tend to occur in the period between October and May, reflecting the relevant patterns in the synoptic conditions leading to the intense precipitation events. In the second part, the focus is on the rainfall-runoff relationships for 13 selected major flash flood events (8 from the North-Western area and 5 from the South-Eastern area) for which rainfall and runoff properties are available. These flash floods are characterised in terms of climatic features of the impacted catchments, duration and amount of the generating rainfall, and runoff ratio. Results show that the rainfall duration is shorter and the rainfall depth lower in the SouthEastern region. The runoff ratios are rather low in both regions, whereas they are more variable in the South-Eastern area. No clear relationship between runoff ratio and rainfall
\end{abstract}

depth is observed in the sample of floods, showing the major influence of rainfall intensity and the initial wetness condition in the runoff generation for these events.

\section{Introduction}

Flash-floods are relatively common flooding events in the Mediterranean region (Llasat et al., 2010). The steep orography surrounding the Mediterranean Sea favours lifting of the low-level layer in an unstable atmosphere, initiation of condensation processes and occurrence of intense precipitation events (Davolio et al., 2009). Moreover, the morphology of the Mediterranean basin with numerous small and steep river catchments can turn the intense runoff generation into severe devastating flash-floods and flooding. The localization of urbanised areas downstream of these small basins enhances the flood risk by increasing the vulnerability of the exposed communities (Montz and Gruntfest, 2002; Llasat et al., 2010). Economic damages and fatalities associated with flash flooding in the Mediterranean region point to the need for better flood risk assessment capabilities. Moreover, the Mediterranean regions have been indeed identified as one of the two most prominent "hot-spots" of the predicted climate change (the other being North Eastern Europe) (Giorgi, 2006). This confirms that the climate in the Mediterranean is especially responsive to global change. A large decrease in mean annual precipitation and increase in precipitation variability during the dry (warm) season are expected as well as a significant generalized warming. The flash flood regimes may be heavily influenced by these changes, through the contrasting impacts on rainfall intensities and initial soil moisture conditions (Collier, 2007). 
The large diversity in climate, synoptic conditions and hydrological properties across the Mediterranean regions leads to large variability in the flash flood regimes. This heterogeneity combines with differences in social, economical and institutional characteristics at local, regional and national level to generate a complex pattern of impacts, responses, and mitigation policies for flash flood risk across the Mediterranean region. A better characterization of flash flood events and their regimes in diverse areas of the Mediterranean region is sought in this work as an important aspect of climate and hydro-meteorological science. Two Mediterranean areas are considered in this work: the North-Western area (including Catalonia, Southern France and Northern Italy, termed Western region hereinafter) and South-Eastern (Israel), termed Eastern region hereinafter. The two regions shows contrasting aspects in climate, synoptic conditions and hydrological properties, while exhibiting similar characteristics in terms of the hydro-meteorological monitoring infrastructure, which permits us to ensure homogeneity in the data collection procedures. This is particularly important, given the small space-time scales of flash floods, relative to the sampling characteristics of conventional rain and discharge measurement networks, which also makes these events particularly difficult to observe and to predict (Borga et al., 2008).

The aim of this work is to characterise the flash flood regimes in the two regions. The analysis is articulated into two parts. In the first part, we examine the peak flow distribution and the seasonality characteristics. For this we identified the major flash floods in the two regions in the last 56 decades. 99 events were identified in this way and the following data were collated: occurrence data, location, peak discharge, catchment area. These data are termed primary data hereinafter, because they represent the minimal data structure required to qualify a flash flood event (Gaume et al., 2009). In the second part, we focus on the more detailed analysis of 13 selected major flash flood events, for which accurate measurements of rainfall and runoff response are available. These flash floods are characterised in terms of climatic features of the impacted catchments, duration and amount of the generating rainfall, and runoff ratio.

The paper is organised as follows. Section 2 describes the synoptic conditions leading to heavy precipitation events in the two Mediterranean regions. Section 3 describes the primary data characterising the collected flash floods in the two areas and the corresponding climatological features. Section 4 examines the rainfall-runoff properties for selected major events. Section 5, finally, reports discussion and conclusions.

\section{The prevailing synoptic conditions leading to heavy precipitation events in the two study areas}

The relationship between atmospheric patterns and precipitation has been widely studied for the Mediterranean region (Romero et al., 1999; Rudari et al., 2005; Ziv et al., 2006; Lana et al., 2007; Martinez et al., 2007; Vicente-Serrano et al., 2009; Nuissier et al., 2011, among others). Different categories of precipitation systems are observed in the Mediterranean areas, according to the season, region and mechanisms of formation. These systems include orographic precipitation, rainy frontal systems, meso-scale convective systems (MCSs) and isolated thunderstorms.

Heavy precipitation events and ensuing flash floods have different characteristics in the two regions considered in this study. These variations are reflected in different seasonality features, with most of the intense precipitation events occuring during the autumn season over the Western Mediterranean region, whereas the peak of heavy precipitation over the Eastern Mediterranean occurs between December and May (Xoplaki et al., 2004).

A number of studies have focused on the features of the synoptic patterns associated to heavy precipitation events (HPE, hereinafter) in the Mediterranean areas ranging from the Iberian coast to North-Western Italy (Rudari et al., 2006; Vicente-Serrano et al., 2009; Nuissier et al., 2011). The general atmospheric circulation processes associated to these HPE may be described as follows (Nuissier et al., 2011). First, the high Mediterranean Sea surface temperature allows large water vapour loading of the atmospheric lower layers at the end of summer. Northern upper-level cold air masses progressing towards the region at this period of the year make the Mediterranean air masses conditionally unstable and advect them toward the Mediterranean coasts where the relief forces their lifting and channelization, leading to the development of convection. Overall, three groups of large scale atmospheric circulation patterns can be identified (Martinez et al., 2008). In the first group, a low pressure centre is located to the SW or W of the Iberian Peninsula, outside the Mediterranean, and an easterly flow blows in the Western Mediterranean, carrying wet Mediterranean air against the eastern flanks of the Iberian Peninsula. Regions in Spain like Eastern Andalusia, Valencia and Catalonia are the most frequently affected by HEP when this kind of pattern is observed. In the second group of synoptic patterns, the main low centre is a large depression located in the Atlantic, to the north or to the northwest of the Iberian Peninsula. The corresponding low-level flow within the Mediterranean ranges from southeasterly to southwesterly, giving a wet Mediterranean air inflow largely in southern France, where HEP can occur. Locations in the Spanish region of Aragon, Central Pyrenees can also be affected by HEP associated to these patterns, probably due to Atlantic air feeding. The third group is characterised by the presence of a clear low pressure centre within the Mediterranean basin that encourages the existence 
of wet Mediterranean air flow or a marked convergence. The location of the Mediterranean low determines where these meteorological factors are presented (Jansà et al., 2001). The Italian and French regions, northeastern Spain and the islands (the Balearics and Corsica) are the areas mostly affected by HEP in association to this group (Martinez et al., 2008).

Israel, located at the Southeastern corner of the Mediterranean, represents in general drier climatic conditions relative to the northwest, with rainfall occurring between October and May and a sharp climatic gradient that changes from Mediterranean climate in the North and center to semiarid and arid in the southern and eastern parts of the region. Over the Mediterranean climate areas of Israel, HPE and extreme flash floods are mainly associated with the Cyprus Low, which is a winter extratropical cyclone synoptic system (Sharon and Kutiel, 1986; Alpert et al., 1990; Krichak et al., 2004; Ziv et al., 2006; Wittenberg et al., 2007; Saaroni et al., 2010). The cold air masses gain moisture while moving over warmer Mediterranean waters and become conditionally unstable. The cyclone dynamics and the intersection of the westerly flow with the shoreline and with the mountain ridges may result in intensive rainfall over the area (Sharon and Kutiel, 1986; Ziv et al., 2006; Saaroni et al., 2010). An upper-level trough extending toward southwestern Turkey induces cold advection aloft enhancing cyclogenic conditions over the Cyprus Low region. A second synoptic system responsible for HPE in the semi-arid and arid regions of Israel over its eastern and southern parts mostly during autumn but also during spring is the Active Red Sea Trough (ARST). The ARST appears as a surface low-pressure trough extending from eastern Africa along the Red Sea towards the Middle East (Ashbel, 1938; Kahana et al., 2002; Dayan and Morin, 2006). Under these circumstances, the Levant region is subjected to a hot and dry south-easterly flow at lower atmospheric levels. This trough is accompanied by an upper level trough extending from the eastern Mediterranean toward the delta of the Nile River leading to cold advection aloft. This differential warming with a large temperature lapse rate throughout the majority of the troposphere enhances static instability stimulating deep convection (Dayan et al., 2001). Over the semi-arid and arid climate regions of Israel (southern and eastern parts) both synoptic systems, the ARST and the Cyprus Low might occur, though the former is more dominant (Kahana et al., 2002; Dayan and Morin; 2006). In addition, since the south-eastern parts of Israel are located on the transition zone between tropical and extratropical systems, some cases associated with the penetration of tropical air masses generating intense rainfall inducing extreme flash floods were detected over these regions (e.g. Ziv, 2001; Morin et al., 2007).

In both areas, mesoscale factors, still poorly understood, contribute to the organization of the convection in a variety of forms ranging from shallow convection associated with the orography to deep convection associated with orographical and/or dynamical forcings which may present a regenerative and stationary character, enhancing their severity. From the hydrological point of view, such HPE events affect small and steep mountainous and coastal watersheds with a high degree of vulnerability due to the increasing anthropogenic pressure, which make their socio-economical impact very severe at times, especially when the soils are already saturated by antecedent rain events.

\section{Flash flood events: selection and analysis of primary data}

A definition of flash flood event was required as a working principle to develop the archive and select the events. An initial definition of flash flood event was based on the duration of the causative rainfall, the size of the catchment impacted by the flood, and the severity of the event. Consistent with the rules adopted by Gaume et al. (2009), duration of the storm event was limited to $24 \mathrm{~h}$ and maximum size of the catchment area was set to $1000 \mathrm{~km}^{2}$. Rainstorm duration is defined here as the time duration of the flood-generating rainfall episodes which are separated by less than $6 \mathrm{~h}$ of rainfall hiatus. As a follow up, these rules were slightly relaxed to include one event with a larger catchment size (Gard event in France, 2002, with a maximum basin area of $1856 \mathrm{~km}^{2}$ ) (Braud et al., 2010). In order to maximise the information content, we used no more than two different catchments for each flood event. These conditions were relaxed in specific conditions to allow the inclusion of some extreme data for small (less than $10 \mathrm{~km}^{2}$ ) and large (few hundreds and more $\mathrm{km}^{2}$ ) catchments to the list. For the Western area, the original data collected by Gaume et al. (2009) were updated by including more recent events collected in the frame of the HYDRATE project (Borga et al., 2010).

Analysis of peak flow distribution and seasonality was carried out by collating and compiling the primary data about the reported flash floods occurred during the last 5-6 decades in the two study regions. Primary data represent the minimal data structure required to qualify a flash flood event: occurrence data, location, peak discharge, catchment area. Detailed precipitation data are often missing, due to the relevant estimation difficulties under flash flood conditions.

The data set includes peak discharge values which vary greatly in magnitude, since they originated from watershed areas ranging from some tens of square kilometers to about $2000 \mathrm{~km}^{2}$ (for the Western region) and to about $1000 \mathrm{~km}^{2}$ for the Eastern region. To limit the impact of watershed areas on the ensuing climatological analyses, the 30 events with the highest "reduced peak discharge" (see below for the relevant definition) were selected for each region (where available). Table 1 reports the characteristics of the collected data, where two indices are introduced to compare the various datasets: the compilation coverage (watershed area multiplied by period of time considered) and the compilation density (number of documented events divided by the coverage). For the 


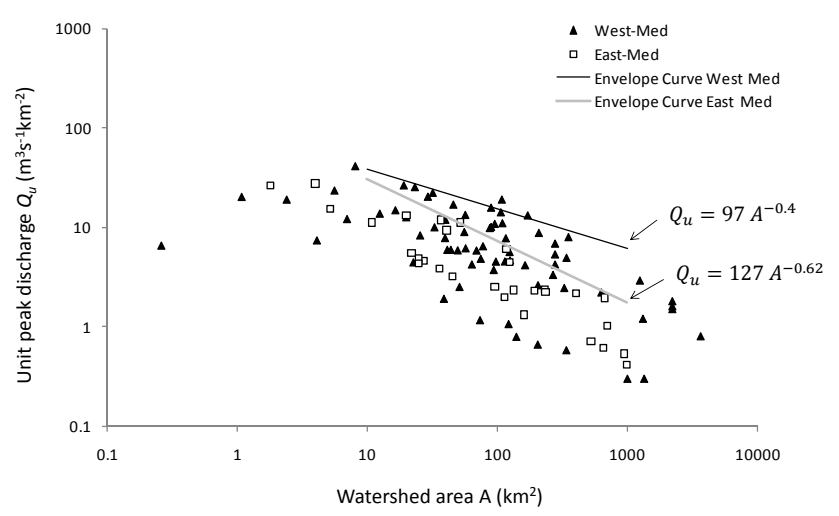

Fig. 1. Peak unit discharges of extreme flash floods in the two regions and envelope curves.

Western area we analysed 69 events, whereas 30 events are considered for the Eastern area.

Envelope curves have been used in this study to appraise the upper bound of flood events in the two areas. An envelope curve shows the relationship between the flood of record of a gauge site and its catchment area in a log-log-diagram. Envelope curves have been widely used in past publications on extreme floods (Gaume et al., 2009; Castellarin, 2007; Herschy, 2005; Costa et al., 1987; Meirovich et al., 1998) and have the advantage of being relatively unaffected by the data compilation density because they are determined by the maximum values of a sample. Figure 1 shows the data and the corresponding envelope curves for the two regions in a $\log -\log$ representation. The envelope curve equation is as follows:

$Q_{\mathrm{u}}=q_{\mathrm{r}} A^{\beta}$

where $Q_{\mathrm{u}}$ is the unit discharge in $\left(\mathrm{m}^{3} \mathrm{~s}^{-1} \mathrm{~km}^{-2}\right), A\left(\mathrm{~km}^{2}\right)$ is the catchment area, $q_{\mathrm{r}}$ is a coefficient supposed to be independent on the catchment area also called "reduced" discharge in $\left(\mathrm{m}^{3} \mathrm{~s}^{-1} \mathrm{~km}^{-2(1+\beta)}\right)$, and $\beta$ is a negative scaling exponent. As suggested by Castellarin (2007), the value of the exponent $\beta$ has been estimated through a linear regression between $\log \left(Q_{\mathrm{u}}\right)$ and $\log (A)$ based on each of the refined data sets. The relationship is drawn for basins with area exceeding $10 \mathrm{~km}^{2}$. For smaller areas, too few data are available and the relationship is not reported. Examination of Fig. 1 shows that the envelope curve for the Eastern region exhibits a more pronounced decreasing with catchment size with respect to the curve of the Western region. A value of $\beta=-0.4$ appears to be the best suited for the Western Med region and is equal to the value previously estimated by Gaume et al. (2009), showing the robustness of those findings which remain unchanged after inclusion of more data concerning recent events. A value of $\beta=-0.62$ provides a better fit for the data from the Eastern Med region. Both values lie in the range of previously calibrated envelope curve parameters for various climatic contexts (Castellarin, 2007;
Table 1. Number of flash flood events listed in the database for each region.

\begin{tabular}{llcrrr}
\hline Region & $\begin{array}{l}\text { Area } \\
\left(10^{6} \mathrm{~km}^{2}\right)\end{array}$ & Period & $\begin{array}{r}\text { Number of } \\
\text { refined events }\end{array}$ & Cov $^{\mathrm{a}}$ & $D^{\mathrm{b}}$ \\
\hline Catalonia & 32 & $1962-2006$ & 9 & 1.1 & 8 \\
France & 18 & $1953-2006$ & 30 & 0.9 & 32 \\
Italy & 95 & $1968-2006$ & 30 & 3.6 & 8 \\
Israel & 20.7 & $1951-2010$ & 30 & 1.03 & 32 \\
\hline
\end{tabular}

${ }^{\mathrm{a}}$ Cov: coverage in year Area. ${ }^{\mathrm{b}} D$ : density in record year ${ }^{-1} \mathrm{Area}^{-1}$.

Jarvis, 1926; Yanovich et al., 1996). The difference between the two relationships may be due both to the effects of storm coverage and to hydrological characteristics. In the Eastern Mediterranean region, the effect of storm coverage may cause a pronounced reduction of the specific peak discharge for large catchments (larger than $100 \mathrm{~km}^{2}$ ), which could lead to a larger slope of the envelope curve. Moreover, for some of the semi-arid and arid catchments in the Eastern Mediterranean region, losses of flood water into channel alluvium may be also an important factor that tends to reduce the specific peak discharge with increasing the catchment area, especially for large catchments with relatively long channels (Shentsis et al., 1999; Dahan et al., 2007). While channel losses might be relatively insignificant immediately downstream of an extreme thunderstorm, the relative significance of channel losses will increase with increasing the travel distances.

The spatial distribution of the reduced flash flood peaks is reported in Fig. 2a and b for the Western and the Eastern region, respectively. Figure 2a shows that events with high flash flood magnitude (events characterized by $q_{\mathrm{r}}$ larger than $\left.70 \mathrm{~m}^{3} \mathrm{~s}^{-1} \mathrm{~km}^{-2(1+\beta)}\right)$, which are those which control the shape of the envelope curve) concentrate over CentralSouthern France and North-Western Italy. The proportion of high intensity events amounts to $23 \%$ for Italy, $20 \%$ for France and $11 \%$ for Catalonia. The proportion of high intensity events is higher in the Eastern Mediterranean region, with a percentage amounting to $27 \%$. Examination of Fig. $2 b$ shows that in this region, the high intensity events tend to cluster in the semi arid and arid regions in the southern portion of the country. This shows that in general, semi-arid and arid catchments in Israel have the potential to produce higher specific peak discharges comparing to the Mediterranean portion of the same region. This may be speculatively attributed to their lower infiltration rates, high gradients, and high rain rates during extreme events (Greenbaum et al., 2006).

The seasonality of flash floods over the two Mediterranean regions has been also examined based on the collected data. The number of events reported for each month is shown for each region in Fig. 3. Examination of this figure shows that the extreme floods in the Western Region tend to occur 


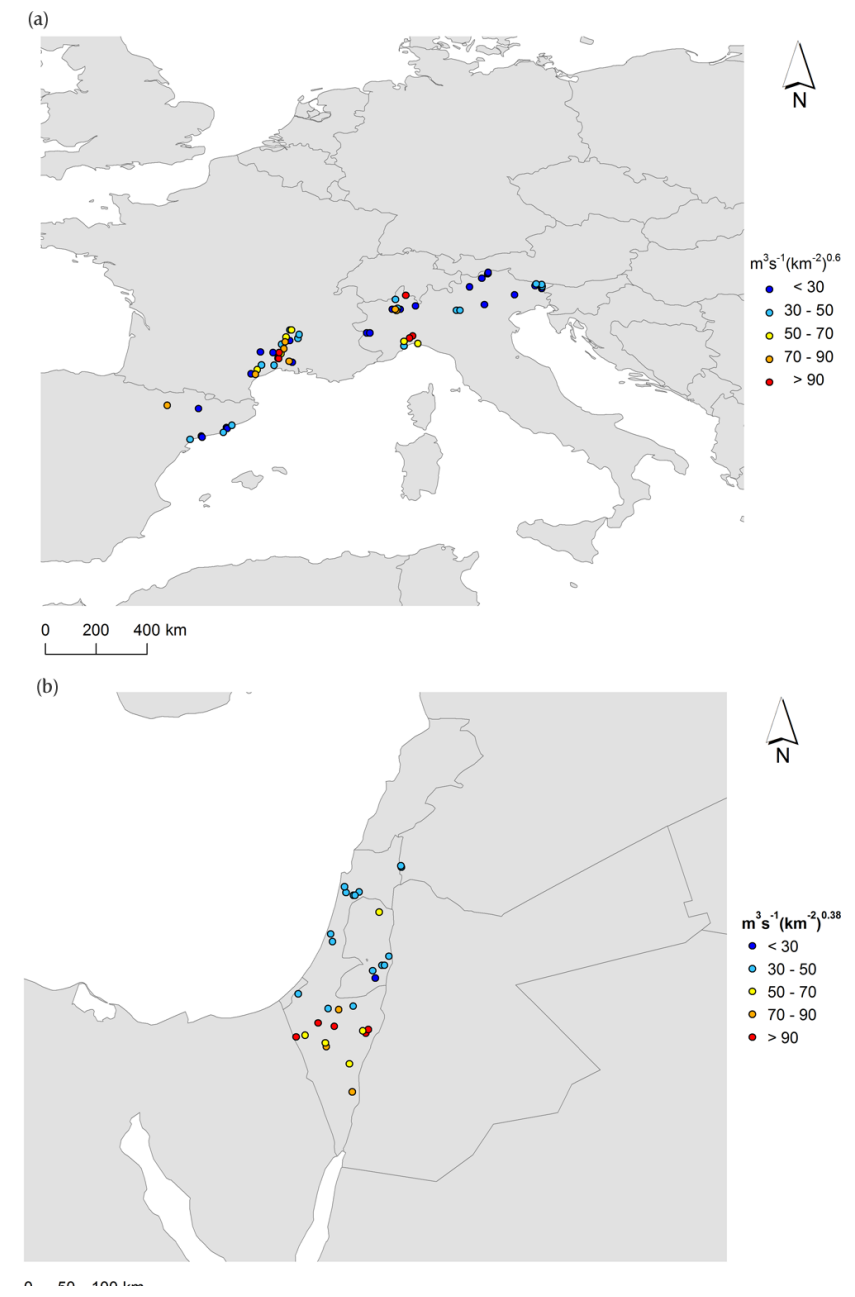

Fig. 2. Atlas of reduced peak discharge $Q_{\mathrm{u}}$ of extreme flash floods in the two Mediterranean regions: (a) Western Region (Spain, France, Italy); (b) Eastern Region (Israel).

in autumn, with a possible slight shift to the summer season (May and June). In the Eastern Region these extremes tend to occur in the autumn and winter seasons (OctoberFebruary) with some events also occurring in spring (MarchMay). This difference in the seasonality shows that the most extreme flash floods in the two Mediterranean Regions are not induced by the same types of meteorological events, hence confirming the influences of the general circulation patterns summarized in Sect. 2. The shift in seasonality from autumn to winter months when moving from the NorthWestern to South-Eastern Mediterranean confirms the findings of Koutroulis et al. (2010), who analysed the seasonality of floods in the island of Crete.

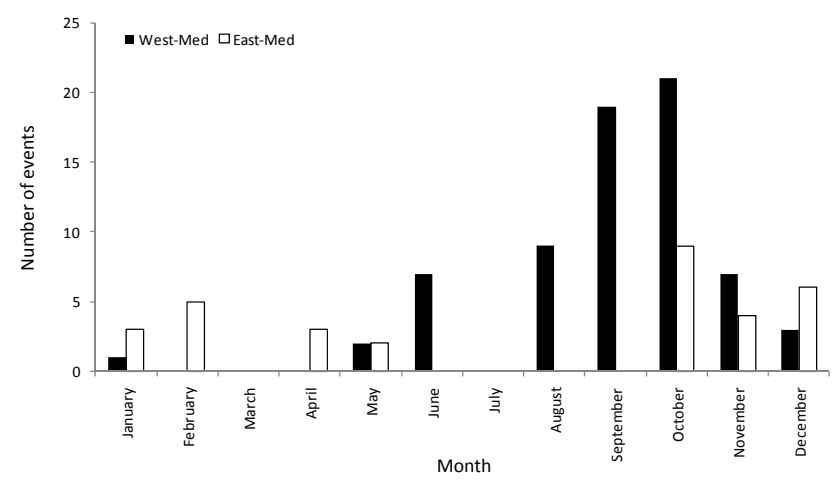

Fig. 3. Number of flash flood occurrences in each month.

\section{Examination of rainfall-runoff properties for selected extreme events}

For the examination of the rainfall-runoff properties, a limited set of major flood events was identified out of the samples collated in the first step of the analysis. For these major events, high-resolution rainfall data and streamgauge data were available. Discharge data availability affords examination of the hydrograph shape as well as estimation of the runoff depth. The quantitative precipitation estimation problem is particularly crucial and difficult in the context of flash floods since the causative rain events may develop at very short space and time scales (Krajewski and Smith, 2002; Bouilloud et al., 2009; Zoccatelli et al., 2011). A methodology was specifically devised for rainfall estimation with the use of radar and raingauge data (Morin and Gabella, 2007; Bouilloud et al., 2009). Depending on the relative locations of the impacted regions and the radar systems available, as well as their operating protocols and maintenance, the quality of the radar datasets may vary a lot for such "event-driven" analyses. The methodology was therefore based on: (1) detailed collection of data and metadata about the radar systems and the raingauge networks (including raingauge data from amateurs and from bucket analysis), (2) analysis of the detection domain and the ground/anthropic clutter for the considered case (Pellarin et al., 2002), (3) implementation of corrections for range-dependent errors, (e.g. screening, attenuation, vertical profiles of reflectivity), and (4) optimisation of the rainfall estimation procedure by means of radarraingauge comparisons at the event duration scale (Bouilloud et al., 2009).

This data availability permits examination of rainfall depth and duration as well as analysis of rainfall-runoff relationships. Severity of storm precipitation and flood response was a further requisite for event selection. The criterion adopted and met by all selected events is that the return period of the flood-generating rainfall exceeds $50 \mathrm{yr}$ at least for some rainfall duration. For some events, the return time was computed based on analysis of radar-derived rainfall maps, which may 


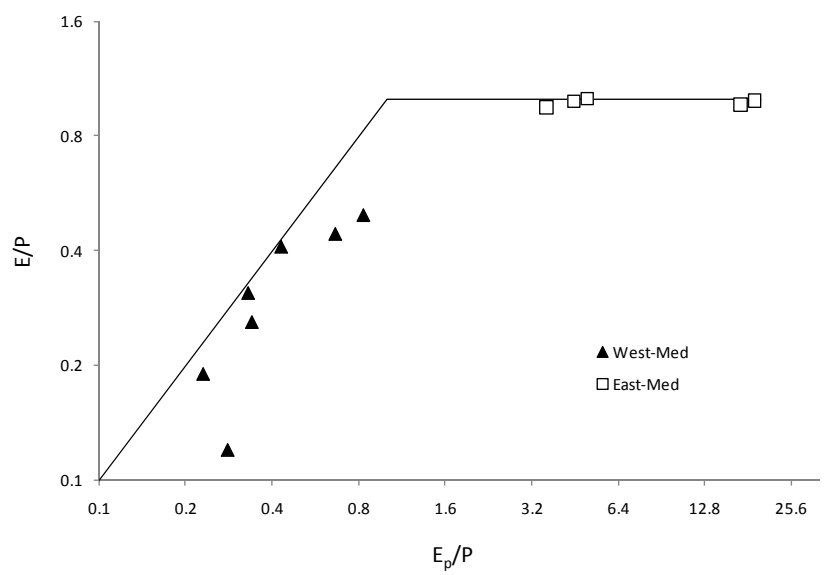

Fig. 4. Budyko diagram.

introduce some uncertainty in the final statistics. The selection of the 50-yr recurrence amount as a threshold for event selection ensures consistency of the study archive with earlier archives of extreme rainfall events (Hershfield, 1961; Schumacher and Johnson, 2006). For some events, either rainfall or peak discharge return period exceeded $500 \mathrm{yr}$ (and sometimes $1000 \mathrm{yr}$ ), for the events of Fella (Italy, 2003) (Norbiato et al., 2007), Gard (France, 2002) (Gaume et al., 2010), and Selska Sora (Slovenia, 2007) (Zanon et al., 2010). Table 2 reports the essential data for the 13 selected flash flood events: 8 from the Western Region and 5 from the Eastern region. For the latter group, 4 are from semi-arid and arid areas and 1 is from the Mediterranean climate area. The seasonality of the events reflects the patterns identified in the previous section, with most events in the Western area occurring during the summer-autumn season, and most events in the Eastern area occurring during autumn-winter.

\subsection{Climate and annual water balance}

The climatic characterisation carried out in this section aims to evaluate the range of climates of the considered case studies and to identify the distribution of the events under different climatic conditions. Flash flood generation may be influenced by climate variability in two ways: in a direct way through the variability of storm characteristics, and indirectly through the seasonality of rainfall and evapotranspiration fluxes which then affect the antecedent catchment conditions for individual storm events (Sivapalan et al., 2005). Moreover, climate may impact in an indirect way upon the runoff generation processes by controlling the geomorphological structure of catchments, through soil formation and erosion processes. An example of the role of climate on the geomorphological properties of catchments is provided by the positive relationship between drainage density and mean annual precipitation (Gregory and Gardiner, 1975).

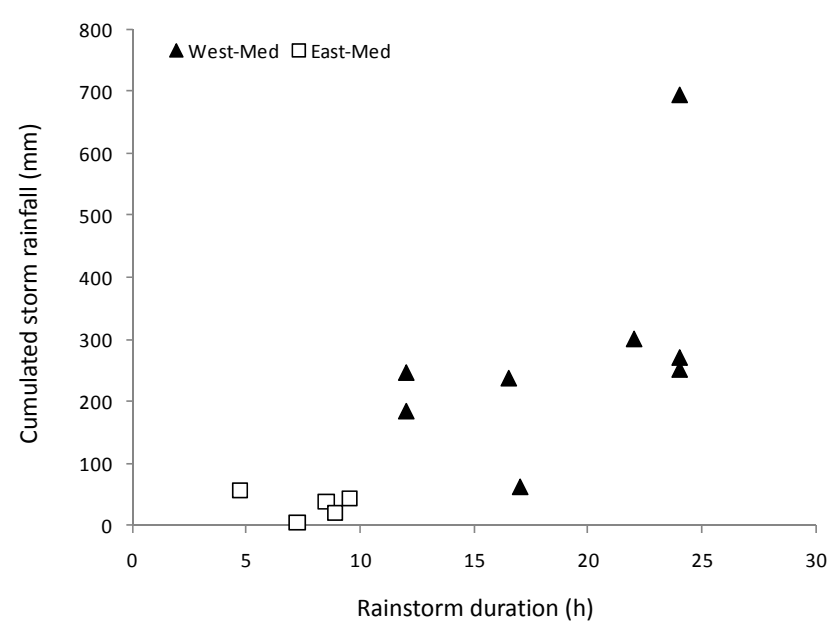

Fig. 5. Rainstorm characteristics: rainstorm duration versus cumulated event rainfall.

The climatic characterisation of the study catchments is provided here by means of Budyko's climatic classification scheme (Budyko, 1974) (Fig. 4). The diagram represents the ratio of evaporation to precipitation versus the ratio of potential evaporation to precipitation thereby combining a metric of the annual water balance and a dryness index. The location of a given catchment on this general relationship represents the relative degree of water versus energy limitation and can inform the interpretation of the controls on catchment runoff.

Figure 4 shows clearly that the catchments in the Western region are concentrated under energy-limited conditions, whereas the catchments in the Eastern region are concentrated under water limited conditions. A number of studies have shown that both the coefficient of variation and the skewness of the distribution of the runoff coefficient increase with increasing the dryness index (Norbiato et al., 2009). Based on these results, we can expect more variable runoff coefficients in the Eastern Mediterranean area than in the Western one. Both areas are characterized by a markedly out of phase seasonal behavior of rainfall and temperature, which may induce important transient soil moisture dynamics.

\subsection{Flood-generating rainfall: amount and duration}

This section examines the characteristics of the triggering rainfall by using two variables: rainfall amount and rainfall duration. Rainstorm duration is defined here as the time duration of the flood-generating rainfall episodes which are separated by less than $6 \mathrm{~h}$ of rainfall hiatus. The combination of rainfall duration and amount is influenced by the local climate and strongly affects the runoff generation during the event. Figure 5 shows the relation between total event rainfall amount versus duration for the two climatic regions considered in this study, taking into account the largest watershed for each flash flood. 
Table 2. Rainfall and runoff properties for selected events in the two Mediterranean regions.

\begin{tabular}{|c|c|c|c|c|c|c|c|}
\hline Basin & Event & $\begin{array}{r}\text { Area } \\
\left(\mathrm{km}^{2}\right)\end{array}$ & $\begin{array}{r}\text { Tot. rain } \\
(\mathrm{mm})\end{array}$ & $\begin{array}{r}\text { Tot. runoff } \\
(\mathrm{mm})\end{array}$ & $\begin{array}{l}\text { Peak dis. } \\
\left(\mathrm{m}^{3} \mathrm{~s}^{-1}\right)\end{array}$ & $\begin{array}{l}\text { Spec. peak dis. } \\
\left(\mathrm{m}^{3} \mathrm{~s}^{-1} \mathrm{~km}^{-2}\right)\end{array}$ & $\begin{array}{r}\text { Runoff } \\
\text { ratio }\end{array}$ \\
\hline \multicolumn{8}{|c|}{ Western Region } \\
\hline Verdouble & 12-13 Nov 1999 & 305 & 693 & 83.2 & 980.0 & 3.21 & 0.12 \\
\hline Gardon d'Anduze & 8-9 Sep 2002 & 542 & 271 & 100.3 & 2744.1 & 5.06 & 0.37 \\
\hline Cervo at Passobreve (2002) & 4 Jun 2002 & 75 & 301 & 123.4 & 359.0 & 4.79 & 0.41 \\
\hline Cervo at Passobreve (2005) & 2-3 Aug 2005 & 75 & 185 & 44.4 & 304.0 & 4.10 & 0.24 \\
\hline Rio Piana at Piana & 3-4 Oct 2006 & 12 & 63.5 & 27.9 & 37.7 & 3.14 & 0.44 \\
\hline Posina at Stancari & 29 Sep 1999 & 116 & 252 & 108.4 & 226.0 & 2.03 & 0.43 \\
\hline Fella at Pontebba & 28 Aug 2003 & 165 & 247 & 98.8 & 680.0 & 4.12 & 0.40 \\
\hline Selska Sora at Zelezniki & 18 Aug 2007 & 103 & 238 & 54.7 & 312.0 & 3.03 & 0.23 \\
\hline \multicolumn{8}{|c|}{ Eastern Region } \\
\hline Zin-Mapal & 13 Oct 1991 & 233 & 56 & 34.5 & 532.2 & 2.28 & 0.61 \\
\hline Merhavia & $27-29$ Oct 2006 & 27 & 44 & 7.3 & 126.1 & 4.69 & 0.17 \\
\hline Arugot & 2 May 2001 & 235 & 39 & 9.1 & 418.1 & 1.78 & 0.23 \\
\hline Neqarot & 23 Dec 1993 & 699 & 21 & 3.7 & 708.4 & 1.01 & 0.17 \\
\hline Teqoa & 5 Nov 1994 & 141 & 5.4 & 2.2 & 158.5 & 1.12 & 0.40 \\
\hline
\end{tabular}

For these storms, the precipitation amount ranges from around $5.4 \mathrm{~mm}$ (Teqoa event, November 1994) to $693 \mathrm{~mm}$ in $24 \mathrm{~h}$ (Verdouble, November 1999). It should be noted that the rainfall amounts (Table 2 and Fig. 5) represent watershed areal averages. For some cases, the focus on gauged basins imposes an observation scale which is poorly related to actual hydrological processes. This is particularly the case for those events which were caused by high intensity rainfall cores dispersed within the gauged watershed (for a more in depth analysis of these cases, see for example Morin et al., 2007 and Yakir and Morin, 2011). This is for instance the case of the Teqoa event of November 1994, for which $5.4 \mathrm{~mm}$ rainfall are reported over an area of $141 \mathrm{~km}^{2}$ (Fig. 6). The runoff is mainly generated by the rainfall core which covers just a small percentage of the watershed. In cases of small rainfall cores like this one the uncertainty affecting rainfall estimation is potentially large because the gauge-adjustment methods use rain gauges often located outside the main cores.

Examination of Fig. 5 shows that the events can be clearly grouped into two different classes according to the climatic and geographic conditions of the two regions. The first group, which includes the events collected in the East Med region, includes storm events which lasted up to ten hours. The corresponding rainfall amount is less than $100 \mathrm{~mm}$, and almost all these events occurred under a dry or semi-arid climate. The second group includes storm events collected in the Western Med Region, and is comprised of events with duration from ten to $24 \mathrm{~h}$. The maximum rainfall amount reported for these events is around $693 \mathrm{~mm}$. An implication from this analysis is that rainfall estimates used for the analysis of the Eastern study area are likely to incorporate huge spatial variability which may obscure the large local values the precipitation may exhibit.

\subsection{Runoff coefficient}

The event runoff coefficient is a key concept in hydrology and an important diagnostic variable for catchment response. Examination of runoff coefficients is useful for catchment comparison to understand how different landscapes filter rainfall into event-based runoff. A specific question in the case of flash floods concerns the relationship with the rainfall amount.

Event runoff coefficients are usually estimated as the ratio of event runoff volume and event rainfall volume. This requires the separation of the event hydrograph into the two components baseflow and event flow, and then the determination of starting time and end time of event flow. In this study, starting time was identified as the time of the first rise of discharge, and the corresponding runoff value was used to determine the baseflow. The time corresponding to the end of event runoff was estimated by separating the recession curve into the components of surface and saturated flow by plotting the recession curve in a semilogarithmic paper (Tallaksen, 1995). These two components are thought to represent different flow paths in the catchment, each characterised by different residence time, the outflow rate of groundwater flow being lower than the recession rate of the surface flow component. The separation between baseflow and event flow was carried out by continuing the baseflow under the major flood peak and then connecting with a straight line to the recession curve as defined above. The ratio of baseflow to peakflow is low in all the floods analysed here: this implies that the uncertainties in the separation between baseflow and event flow regard essentially the definition of the end time of event flow and hence to the analysis of the recession curve. 
(a)

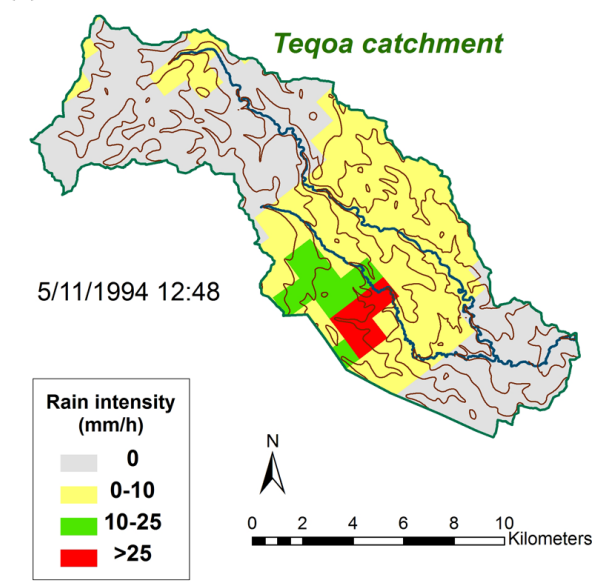

(b)

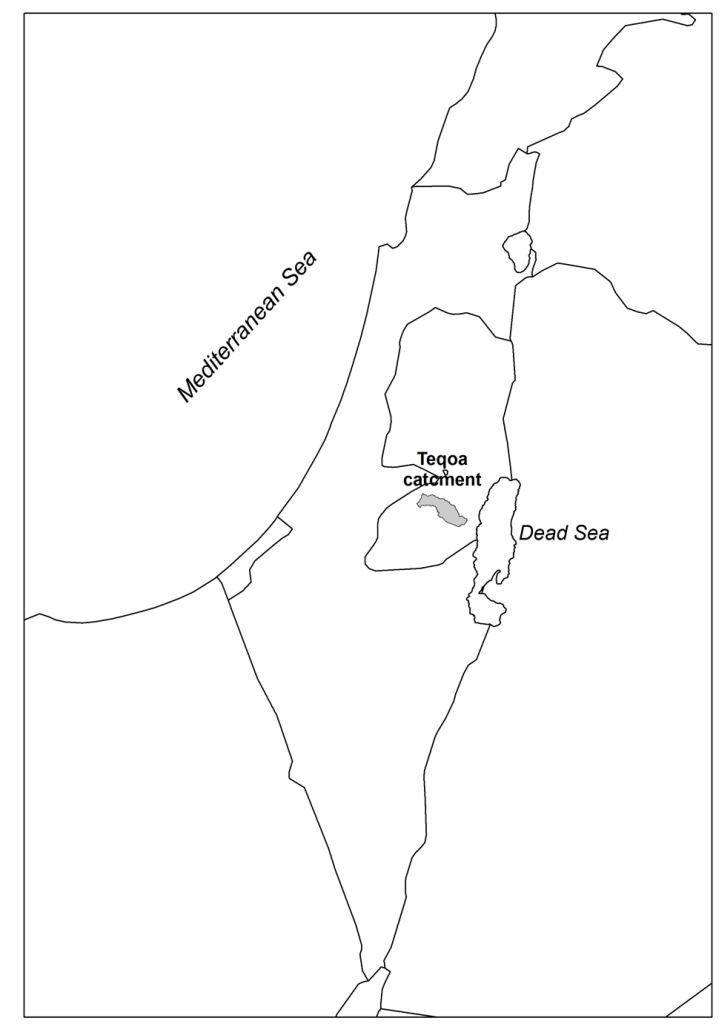

Fig. 6. Teqoa Event occurring in November 1994. (a) Radar-based rainfall intensities over the Teqoa catchment for 12:48 (local time), brown contour lines represent elevation $(0-900 \mathrm{~m}$ in $100 \mathrm{~m}$ intervals), and, (b) general location of the Teqoa catchment.

The relation between event runoff coefficient and the event cumulative rainfall is reported in Fig. 7.

The event runoff coefficients of the extreme flash flood events considered here are rather low, with a mean value of 0.33 for the events observed in the Western region and of 0.32 for those considered in the Eastern area. This agrees with earlier results obtained by Marchi et al. (2010) for flash

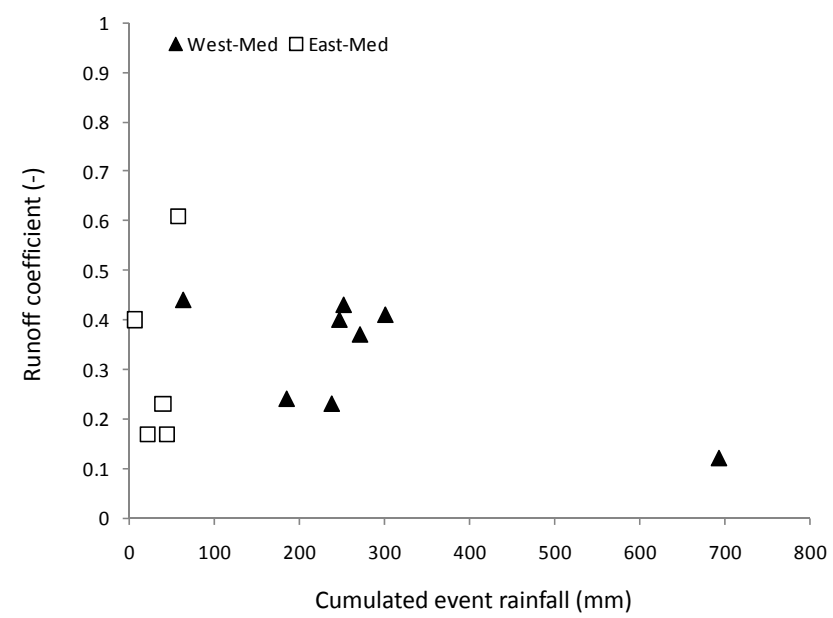

Fig. 7. Relation between event runoff coefficient and event cumulated rainfall.

floods observed in Europe. As expected, the variability of the runoff ratio is larger for the Eastern Med events (with a 0.17-0.61 range) than for the Western Med events (with a $0.12-0.44$ range). The larger variability reported for the Eastern Med events may be due to the scale of rainfall observation for gauged basins, which may not be completely relevant to explain the actual hydrological processes, and the potential larger uncertainty in rainfall estimation, as reported above. This problem is more acute for the Eastern Med events, which are characterised by a smaller spatial extent of flood-triggering storms with respect to the Western Med cases.

Overall, the values of runoff ratio are distributed in a wide interval over the range of precipitation depth and fail to show any relationship with the water input. There are several possible explanations for these results. Considering the meteorological factors, the runoff depth generated under prevailing infiltration excess runoff-generation mechanisms may be more likely controlled by rainfall intensity than from runoff depth. Moreover, a further potential source of heterogeneity is represented by the variability of the initial soil moisture conditions. The initial soil moisture combines with the subsurface water storage capacity to determine the amount of water input that needs to be stored in the soil before event runoff may start, i.e. the so-called initial losses. These losses may influence the runoff depth in a way which is unrelated to the rainfall depth-runoff ratio relationship. Wood et al. (1990) note that for large floods the role of antecedent soil moisture for flood response should decrease with increasing return interval. However, a number of studies (Sturdevant-Rees et al., 2001; Gaume et al., 2004; Borga et al., 2007) have shown considerable impact of initial soil moisture conditions on runoff from extreme flash floods. Finally, uncertainty in rainfall estimation, which may be significant for these cases, may further contribute to the runoff coefficient scatter. 


\section{Conclusions}

Primary data concerning 99 flash flood events occurring in the Western and Eastern region of the Mediterranean basin and high-resolution hydrological data concerning 13 major flash floods were collected and examined to explore differing flood seasonality, relationship between flood peak and basin size, and rainfall-to-runoff properties. The main results are summarised below.

- Examination of data shows a peculiar seasonality effect on flash flood occurrence, with events in the Western region (Catalonia, France, northern Italy) mostly occurring in autumn, whereas events in the Eastern region commonly occur in the period from October to May, reflecting different climatic forcing.

- Results show that the envelope curve for the Eastern region exhibits a more pronounced decreasing with catchment size with respect to the curve of the Western region. The differences between the two relationships reflect changes in the effects of storm coverage and hydrological characteristics between the two regions.

- Analysis of the extreme cases for which high-resolution data are available shows that (i) rainfall duration is generally shorter, and (ii) rainfall depth is lower for the events in the Eastern region with respect to those in the Western region.

- The event runoff coefficients of the extreme flash flood events considered here are rather low, with a mean value of 0.33 for the events observed in the Western region and of 0.32 for those considered in the Eastern area. This agrees with earlier results obtained by Marchi et al. (2010) for flash floods observed in Europe. This clearly points out the need to account for hydrological conditions in the forecasting of flash floods. However, the variability associated to the events observed in the Eastern region is higher than that computed for the events collected in the Western area.

- In both regions, no clear relationship between runoff ratio and rainfall depth may be identified. This points out the major influence of rainfall intensity (with respect to rainfall depth) and of the initial wetness conditions in the generation of runoff for these events.

Acknowledgements. The authors wish to thank the following organizations for their assistance in data gathering concerning the events over Israel: E.M.S Mekorot (radar data), Israel Meteorological Service (raingauge data), and Israel Hydrological Service (discharge data). The research presented in this paper has been carried out as part of the EU RTD Project HYDRATE (European Commission, Sixth Framework Programme, Contract No. 037024). This study would not have been possible without the support from the HYDRATE project partners for the collection and analysis of the data and observations over the North-Western Mediterranean region. We greatly appreciate the recommendations of Silas Michaelidis, and an anonymous reviewer for improvements to the manuscript.

Edited by: L. Garrote

Reviewed by: S. C. Michaelides and another anonymous referee

\section{References}

Alpert, P., Neeman, B. U., and Shay-El, Y.: Climatological analysis of Mediterranean cyclones using ECMWF data, Tellus, 42A, 6577, 1990.

Ashbel, D.: Great floods in Sinai peninsula, Palestine, Syria and the Syrian desert, and the influence of the Red Sea on their formation, Q. J. Roy. Meteorol. Soc., 64, 635-639, 1938.

Borga, M., Boscolo, P., Zanon, F., and Sangati, M.: Hydrometeorological analysis of the 29 August 2003 flash flood in the Eastern Italian Alps, J. Hydrometeorol., 8, 1049-1067, doi:10.1175/JHM593.1, 2007.

Borga, M., Gaume, E., Creutin, J. D., and Marchi, L.: Surveying flash flood response: gauging the ungauged extremes, Hydrol. Process., 22, 3883-3885, 2008.

Borga, M., Anagnostou, E. N., Blöschl, G., and Creutin, J.-D.: Flash Floods: observations and analysis of hydrometeorological controls, J. Hydrol., 394, 1-3, doi:10.1016/j.jhydrol.2010.07.048, 2010.

Bouilloud, L., Delrieu, G., Boudevillain, B., Borga, M., and Zanon, F.: Radar rainfall estimation for the post-event analysis of a Slovenian flash-flood case: application of the Mountain Reference Technique at C-band frequency, Hydrol. Earth Syst. Sci., 13, 1349-1360, doi:10.5194/hess-13-1349-2009, 2009.

Braud, I., Roux, H., Anquetin, S., Maubourguet, M.-M., Manus, C., Viallet, P., and Dartus, D: The use of distributed hydrological models for the Gard 2002 flash flood event: Analysis of associated hydrological processes, J. Hydrol., 394, 162-181, 2010.

Budyko, M. I.: Climate and life, Academic, New York, 1974.

Castellarin, A.: Probabilistic envelope curves for design flood estimation at ungauged sites, Water Resour. Res., 43, W044006, doi:10.1029/2005WR004384, 2007.

Collier, C.: Flash flood forecasting: what are the limits of predictability?, Q. J. Roy. Meteorol. Soc., 133, 3-23, 2007.

Costa, J. E.: A comparison of the largest rainfall-runoff floods in the Unites States with those of the People's Republic of China and the world, J. Hydrol., 96, 101-115, 1987.

Dahan, O., Shani, Y., Enzel, Y., Yechieli, Y., and Yakirevich, A.: Direct measurements of floodwater infiltration into shallow alluvial aquifers, J. Hydrol., 344, 157-170, doi:10.1016/j.jhydrol.2007.06.033, 2007.

Davolio, S., Buzzi, A., and Malguzzi, P.: Orographic triggering of long lived convection in three dimensions, Meteorol. Atmos. Phys., 103, 35-44, 2009.

Dayan, U. and Morin, E.: Flash flood-producing rainstorms over the Dead Sea: A review, in: New Frontiers in Dead Sea Paleoenvironmental Research, edited by: Enzel, Y., Agnon, A., and Stein, M., Geological Society of America Special Paper 401, 53-62, 2006

Dayan, U., Ziv, B., Margalit, A., Morin, E., and Sharon, D.: A severe autumn storm over the Middle-East: synoptic and mesoscale convection analysis, Theor. Appl. Climatol., 69, 103-122, 2001. 
Gaume, E., Livet, M., Desbordes, M., and Villeneuve, J. P.: Hydrological analysis of the river Aude, France, flash flood on 12 and 13 November 1999, J. Hydrol., 286, 135-154, 2004.

Gaume, E., Valerie, B., Pietro, B., Newinger, O., Barbuc, M., Bateman, A., Blaškovicová, L., Blöschl, G., Borga, M., Dumitrescu, A., Daliakopoulos, J., Garcia, J., Irimescu, A., Kohnova, S., Koutroulis, A., Marchi, L., Matreata, S., Medina, V., Preciso, E., Sempere-Torres, D., Stancalie, G., Szolgay, J., Tsanis, I., Velasco, D., and Viglione, A.: A compilation of data on European flash floods, J. Hydrol., 367, 70-78, doi:10.1016/j.jhydrol.2008.12.028, 2009.

Gaume, E., Gaál, L., Viglione, A., Szolgay, J., Kohnová, S., and Blöschl, G. : Bayesian MCMC approach to regional flood frequency analyses involving extraordinary flood events at ungauged sites, J. Hydrol., 394, 101-117, 2010.

Giorgi, F.: Climate change hot-spots, Geophys. Res. Lett., 33, L08707, doi:10.1029/2006GL025734, 2006.

Greenbaum, N., Ben-Zvi, A., Haviv, I., and Enzel, Y.: The hydrology and paleohydrology of the Dead Sea tributaries, in: New Frontiers in Dead Sea Paleoenvironmental Research, edited by: Enzel, Y., Agnon, A., and Stein, M., Geological Society of America Special Paper 401, 63-93, 2006.

Gregory, K. J. and Gardiner, V.: Drainage density and climate, Z. Geomorphol. N. F., 19, 287-298, 1975.

Herschy, R. W.: The world's maximum observed floods, Flow Meas. Instrum., 13, 231-235, 2005.

Hershfield, D. M.: Rainfall Frequencies Atlas of the United States for Durations from 30 Minutes to 24 Hours and Return Periods from 1 to 100 Years, Technical Paper No. 40, Washington, DC, US Weather Bureau, 1961.

Jansà, A., Genovés, A., Picornell, M., Campins, J., and Riosalido, O. C. R.: Western Mediterranean cyclones and heavy rain. Part 2: statistical approach, Meteorol. Appl., 8, 43-56, 2001.

Jarvis, C. S.: Flood flow characteristics, T. Am. Soc. Civ. Eng., 89, 985-1032, 1926.

Kahana, R., Ziv, B., Enzel, Y., and Dayan, U.: Synoptic climatology of major floods in the Negev Desert, Israel, Int. J. Climatol., 22, 867-822, 2002.

Koutroulis, A. G., Tsanis, I. K., and Daliakopoulos, I. N.: Seasonality of floods and their hydrometeorologic characteristics in the island of Crete, J. Hydrol., 394, 90-100, 2010.

Krajewski, W. F. and Smith, J. A.: Radar hydrology: Rainfall estimation, Adv. Water Res., 25, 1387-1394, 2002.

Krichak, S. O., Alpert, P., and Dayan, M.: The role of atmospheric processes associated with hurricane Olga in the December 2001 Floods in Israel, J. Hydrometeorol., 5, 1259-1270, 2004.

Lana, A., Campins, J., Genovés, A., and Jansà, A.: Atmospheric patterns for heavy rain events in the Balearic Islands, Adv. Geosci., 12, 27-32, doi:10.5194/adgeo-12-27-2007, 2007.

Llasat, M. C., Llasat-Botija, M., Prat, M. A., Porcú, F., Price, C., Mugnai, A., Lagouvardos, K., Kotroni, V., Katsanos, D., Michaelides, S., Yair, Y., Savvidou, K., and Nicolaides, K.: High-impact floods and flash floods in Mediterranean countries: the FLASH preliminary database, Adv. Geosci., 23, 47-55, doi:10.5194/adgeo-23-47-2010, 2010.

Marchi, L., Borga, M., Preciso, E., and Gaume, E.: Characterisation of selected extreme flash floods in Europe and implications for flood risk management, J. Hydrol., 394, 118-133, doi:10.1016/j.jhydrol.2010.07.017, 2010.
Martìnez, M. D., Lana, X., Burgueno, A., and Serra, C.: Spatial and temporal daily rainfall regime in Catalonia (NE Spain) derived from four precipitation indices, years 1950-2000, Int. J. Climatol., 27, 123-138, 2007.

Meirovich, L., Ben-Zvi, A., Shentsis, I., and Yanovich, E.: Frequency and magnitude of runoff events in the arid Negev of Israel, J. Hydrol., 207, 204-219, 1998.

Montz, B. E. and Gruntfest, E.: Flash flood mitigation: recommendations for research and applications, Environ. Hazards, 4, 1522, 2002.

Morin, E. and Gabella, M.: Radar-based quantitative precipitation estimation over Mediterranean and dry climate regimes, J. Geophys. Res., 112, D20108, doi:10.1029/2006JD008206, 2007.

Morin, E., Harats, N., Jacoby, Y., Arbel, S., Getker, M., Arazi, A., Grodek, T., Ziv, B., and Dayan, U.: Studying the extremes: hydrometeorological investigation of a flood-causing rainstorm over Israel, Adv. Geosci., 12, 107-114, doi:10.5194/adgeo-12107-2007, 2007.

Norbiato, D., Borga, M., Sangati, M., and Zanon, F.: Regional frequency analysis of extreme precipitation in the eastern Italian Alps and the August 29, 2003 flash flood, J. Hydrol., 345, 149166, doi:10.1016/j.jhydrol.2007.07.009, 2007.

Norbiato, D., Borga, M., Merz, R., Blöschl, G., and Carton, A.: Controls on event runoff coefficients in the eastern Italian Alps, J. Hydrol., 375, 312-325, 2009.

Nuissier, O., Joly, B., Joly, A., Ducrocq, V., and Arbogast, P.: A statistical downscaling to identify the large-scale circulation patterns associated with heavy precipitation events over southern France, Q. J. Roy. Meteorol. Soc., 137, 1812-1827, doi:10.1002/qj.866, 2011.

Pellarin, T., Delrieu, G., Saulnier, G. M., Andrieu, H., Vignal, B., and Creutin, J. D.: Hydrologic visibility of weather radar systems operating in mountainous regions: case study for the Ardeche catchment (France), J. Hydrometeorol., 3, 539-555, 2002.

Romero, R., Sumner, G., Ramis, C., and Genove, A.: A classification of the atmospheric circulation patterns producing significant daily rainfall in the Spanish Mediterranean area, Int. J. Climatol., 19, 765-785, 1999.

Rudari, R., Entekhabi, D., and Roth, G.: Large-scale atmospheric patterns associated with mesoscale features leading to extreme precipitation events in Northwestern Italy, Adv. Water Res., 28, 601-614, 2005.

Saaroni, H., Halfon, N., Ziv, B., Alpert, P., and Kutiel, H.: Links between the rainfall regime in Israel and location and intensity of Cyprus lows, Int. J. Climatol., 30, 1014-1025, 2010.

Sharon, D. and Kutiel, H.: The distribution of rainfall intensity in Israel, its regional and seasonal variations and its climatological evaluation, J. Climatol., 6, 277-291, 1986.

Shentsis, I., Meirovich, L., Ben-Zvi, A., and Rosenthal, E.: Assessment of transmission losses and groundwater recharge from runoff events in a Wadi under shortage of data on lateral inflow, Negev, Israel, Hydrol. Process., 13, 1649-1663, 1999.

Schumacher, R. S. and Johnson R. H.: Characteristics of U.S. extreme rain events during 1999-2003, Weather Forecast., 21, 6985,2006

Sivapalan, M., Blöschl, G., Merz, R., and Gutknecht, D.: Linking flood frequency to long-term water balance: Incorporating effects of seasonality, Water Resour. Res., 41, 1-17, 2005.

Sturdevant-Rees, P., Smith, J. A., Morrison, J., and Baeck, M. 
L.: Tropical storms and the flood hydrology of the central Appalachians, Water Resour. Res., 37, 2143-2168, 2001.

Tallaksen, L. M.: A review of baseflow recession analysis, J. Hydrol., 165, 349-370, 1995.

Vicente-Serrano, S. M., Beguería, S., López-Moreno, J. I., El Kenawy, A. M., and Angulo Martínez, M.: Daily atmospheric circulation events and extreme precipitation risk in Northeast Spain: the role of the North Atlantic Oscillation, Western Mediterranean Oscillation, and Mediterranean Oscillation, J. Geophys. Res. Atmos., 114, D08106, doi:10.1029/2008JD011492, 2009.

Wittenberg, L., Kutiel, H., Greenbaum, N., and Inbar, M.: Shortterm changes in the magnitude, frequency and temporal distribution of floods in the Eastern Mediterranean region during the last 45 years - Nahal Oren, Mt. Carmel, Israel, Geomorphology, 84, 181-191, 2007.

Wood, E. F., Sivapalan, M., and Beven, K.: Similarity and scale in watershed storm response, Rev. Geophys., 28, 1-18, 1990.

Xoplaki, E., Gonzalez-Rouco, J. F., Luterbacher, J., and Wanner, H.: Wet season Mediterranean precipitation variability: influence of large-scale dynamics and trends, Clim. Dynam., 23, 63-78, 2004.

Yakir, H. and Morin, E.: Hydrologic response of a semi-arid watershed to spatial and temporal characteristics of convective rain cells, Hydrol. Earth Syst. Sci., 15, 393-404, doi:10.5194/hess15-393-2011, 2011.
Yanovich, E., Ben-Zvi, A., and Shentsis, I.: Enveloping curves for maximum discharges in the Negev wadis. Rep. HYD/6/96, Israel Hydrological Service, Jerusalem, Israel (in Hebrew), 1996.

Zanon, F., Borga, M., Zoccatelli, D., Marchi, L., Gaume, E., Bonnifait, L., and Delrieu, G.: Hydrological analysis of a flash flood across a climatic and geologic gradient The September 18, 2007 event in Western Slovenia, J. Hydrol., 394, 182-197, doi:10.1016/j.jhydrol.2010.08.020, 2010.

Ziv, B.: A subtropical rainstorm associated with a tropical plume over Africa and the Middle East, Theor. Appl. Climatol., 69, 91102, doi:10.1007/s007040170037, 2001.

Ziv, B., Dayan, U., Kushnir, Y., Roth, C., Enzel, Y., and Ziv, B.: Regional and global atmospheric patterns governing rainfall in the southern Levant, Int. J. Climatol., 26, 55-73, 2006.

Zoccatelli, D., Borga, M., Viglione, A., Chirico, G. B., and Blöschl, G.: Spatial moments of catchment rainfall: rainfall spatial organisation, basin morphology, and flood response, Hydrol. Earth Syst. Sci., 15, 3767-3783, doi:10.5194/hess-15-37672011, 2011. 